\title{
Microsatellite loci from Lanyu scops owl (Otus elegans botelensis) and their cross-species application in four species of strigidae
}

\author{
Yu-Cheng Hsu ${ }^{1}$, Shou-Hsien $\mathrm{Li}^{2}$, Yao-Sung Lin ${ }^{1}, \&$ Lucia Liu Severinghaus ${ }^{3, *}$ \\ ${ }^{1}$ Institute of Ecology and Evolutionary Biology, National Taiwan University, Taipei, 106, Taiwan ROC; \\ ${ }^{2}$ Department of Life Science, National Taiwan Normal University, Taipei, 116, Taiwan ROC; ${ }^{3}$ Research \\ Center for Biodiversity, Academia Sinica, Taipei, 115, Taiwan ROC \\ (*Corresponding author: Phone: +886-2-27899542; Fax: +886-2-27858059; E-mail: zobbowl@gate. \\ sinica.edu.tw)
}

Received 24 February 2005; accepted 5 April 2005

Key words: DNA polymorphism, genotyping, microsatellite, microsatellites, Otus elegans, strigidae

\begin{abstract}
We developed six new microsatellite markers containing tetranucleotide repeat motifs (GATA/CTAT) for Lanyu scops owl (Otus elegans botelensis) from an enriched partial library. All these loci are polymorphic and conform to Hardy-Weinberg equilibrium. We cross-species tested these and 12 other microsatellite primer pairs previously developed from $O$. elegans on four other species of owls $(O$. lettia, O. spilocephalus, $O$. scops, and Ninox scutulata). Results showed that the degree of polymorphism decreased with increasing phylogenetic distance to $O$. elegans. Most loci $(66.7,83.3$, and $100 \%$ ) were polymorphic in the three Otus owls but only five $(27.8 \%)$ were polymorphic in $N$. scutulata. These microsatellites should be very useful genetic markers in studying the mating system, population genetics, and conservation of other little studied Old World Otus owls.
\end{abstract}

Microsatellite molecular marker system has gained great importance in studies as diverse as population ecology, genetic mating systems, relatedness analyses, population differentiation, effects of genetic similarity or inbreeding on fitness, and evaluation of conservation units (DeSalle and Schierwater 1998; Beaumont and Bruford 1999; Pemberton et al. 1999). Microsatellite has many advantages, including being highly polymorphic, easy to score, and in accordance with Mendelian inheritance; before enough polymorphic loci can be identified for use, however, researchers usually must conduct a labor-intensive and cost expensive cloning procedure. Furthermore, a large number of microsatellite loci are usually needed in order to reach better resolution in relatedness analyses (Blouin 2003). Exploring the cross-species applicability of existing microsatellite primers is therefore an advisable and economical first step for a study. In Strigidae, as far as we know, microsat- ellites have only been developed for Athene cunicularia (Korfanta et al. 2002), Bubo bubo, (Isaksson and Tegelström 2002), Strix occidentalis lucida (Thode et al. 2002) and Otus elegans botelensis (Hsu et al. 2003). Only B. bubo primers were cross-species tested in Aegolius funereus with limited success (Beheim et al. 2002). In this paper, we report the primer pairs for six novel tetranucleotide microsatellite loci isolated from $O$. e. botelensis, and the results of cross-species testing of 18 pairs of $O . e$. botelensis microsatellite primers on four other species of owls, namely collard scops owl (O. lettia), mountain scops owl (O. spilocephalus), oriental scops owl (O. sunia), and brown hawk owl (Ninox scutulata).

The O. e. botelensis is a small Old World Otus owl endemic to Lanyu Island $\left(22^{\circ} \mathrm{N}, 121^{\circ} 5^{\prime} \mathrm{E}\right)$, a $45.7 \mathrm{~km}^{2}$ island $60 \mathrm{~km}$ southeast of Taiwan. We have been studying this subspecies since 1985 (e.g. Severinghaus and Rothery 2001). Since 1999, we 
collected about $20 u 1$ blood from each bird caught during routine banding by brachial venipuncture and preserved the blood in Queen's lysis buffer (Seutin et al. 1991). We extracted DNA from blood using a method modified from Gemmell and Akiyama (1996), and analyzed the characteristics of the microsatellite loci with DNA samples from 100 adult owls with unknown relationship.

We sequenced plasmid DNA from an enriched partial library constructed in a previous study (Hsu et al. 2003) and found six additional clones containing GATA/CTAT repeat motif. We designed primers for these microsatellites according to the sequences flanking the repeat motifs, using FastPCR 2.3.10 software (available at http://www.biocenter.helsinki.fi/bi/bare-1_html/oligos.htm). After optimizing the polymerase chain reaction (PCR) condition, we labeled each forward primer with HEX, FAM, or TAMRA fluorescent dye.

We amplified each sample under PCR in a $10 \mu \mathrm{l}$ reaction volume containing about $30 \mathrm{ng}$ genomic DNA, $0.3 \mu \mathrm{M}$ each primer, $0.5 \mathrm{mM}$ dNTP, $10 \mathrm{mM}$ Tris-HCl, pH 9.0, $50 \mathrm{mM} \mathrm{KCl}$, $0.01 \%(\mathrm{w} / \mathrm{V})$ gelatin, $0.1 \%$ Triton X-100, $0.4 \mathrm{U}$ Pro Taq DNA polymerase (Protech) and 2.0 or $2.5 \mathrm{mM} \mathrm{MgCl}_{2}$ (see Table 1). PCR conditions included a denaturing period of $3 \mathrm{~min}$ at $94^{\circ} \mathrm{C}$, followed by 34 cycles of $94^{\circ} \mathrm{C}$ for $30 \mathrm{~s}$, the optimal annealing temperature for each primer pair (as given in Table 1) for $30 \mathrm{~s}$, and $72^{\circ} \mathrm{C}$ for $30 \mathrm{~s}$, then ending with a final extension period of $3 \mathrm{~min}$ at $72^{\circ} \mathrm{C}$. We used iCycler thermal cycler (Bio-Rad) for all the PCR work, and MegaBACE 1000 autosequencer (Amersham Biosciences) to electrophorese the PCR products. We analyzed the sizes of alleles with the software Genetic Proflier 2.0 (Amersham Biosciences), and examined the characteristics of these loci with CERVUS 2.0 software (Marshall et al. 1998). A test for linkage disequilibrium of the six novel loci, as well as the twelve loci previously published was conducted using FSTAT 2.9.3.2 (Goudet 2001).

For cross-species application tests, we extracted DNA from blood samples of 23 O. spilocephalus, 37 O. lettia and $15 \mathrm{~N}$. scutulata that came from the Government Office of Stan-Hsiang, Miaoli County, Taiwan. These birds were accidentally caught in a pest control program. Blood samples of 27 O. sunia came from the Wildbird Rescue Center of Wild Bird Society of Taipei, Taiwan, the Beijing Raptor Rescue Center, China,

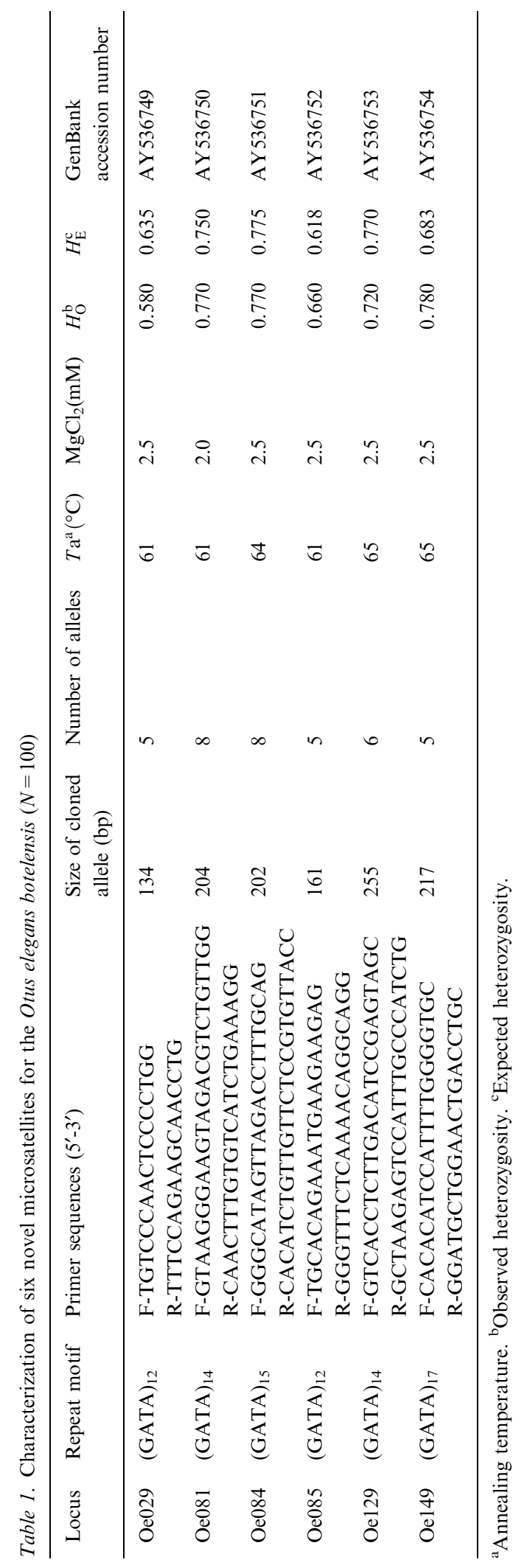




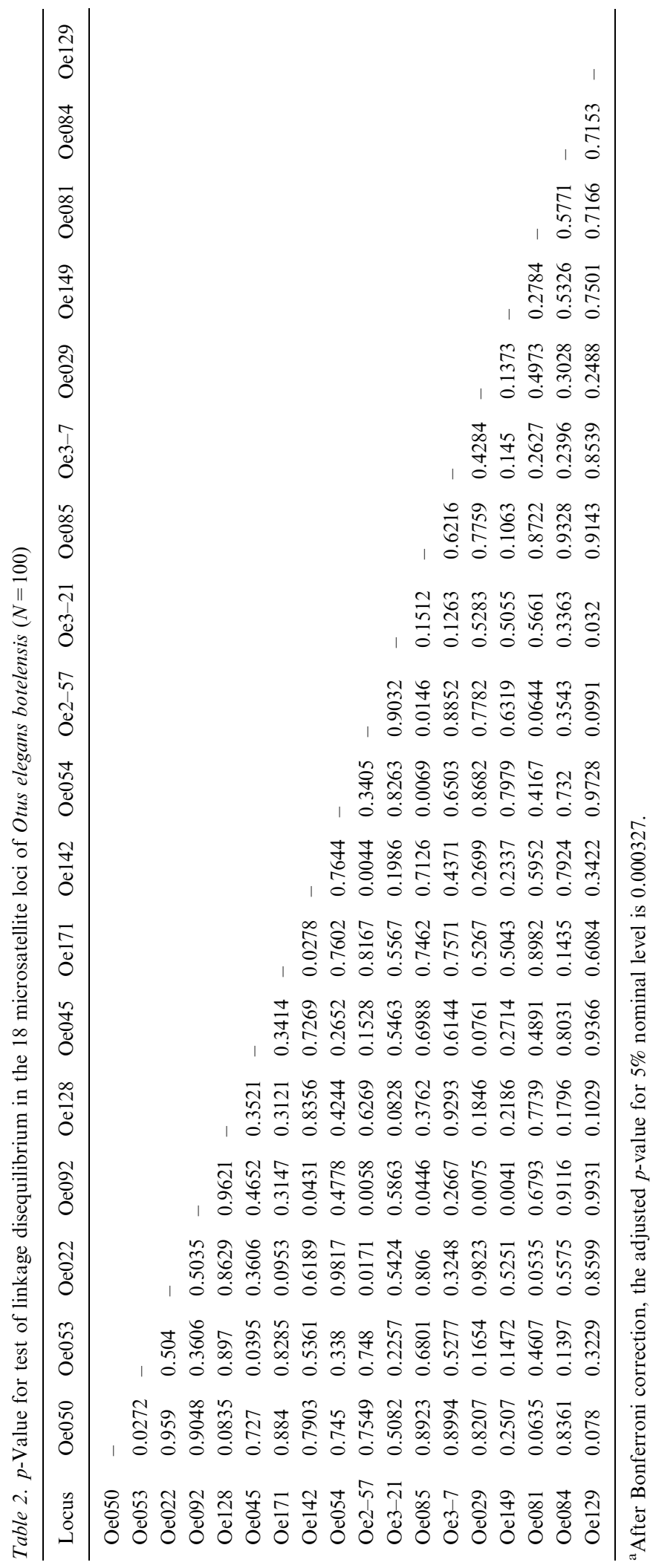


and Maoershan Banding Station, Heilungjiang Province, China. For each locus, all the PCR parameters followed the same regime as that set for $O$. e. botelensis.

The characteristics of the six new microsatellite loci for $O$. e. botelensis are listed in Table 1. None of these loci showed significant deviation from Hardy-Weinberg equilibrium. Although O. e. botelensis is an island endemic with an estimated population size fewer than 1000 individuals (Severinghaus, unpublished data), all six loci are highly polymorphic, with 5-8 alleles per locus and heterozygosity between 0.58 and 0.78 . These characteristics are similar to those found in the 12 microsatellite loci we isolated previously ( $\mathrm{Hsu}$ et al. 2003). There was no evidence of linkage equilibrium among the 18 loci, after adjusting the significance level for multiple comparisons with sequential Bonferroni correction (Table 2).

The results of cross-species application of these six microsatellite primer pairs and the 12 pairs we isolated before (Hsu et al. 2003) are summarized in Table 2. The degree of polymorphism (number of polymorphic loci, number of alleles per polymorphic locus, and overall observed heterozygosity) of these eighteen loci decreased as the species' phylogenetic relationship to $O$. e. botelensis increased. This is consistent with the decreasing cross-species applicability of swallow (Hirundo rustica) and pied flycatcher (Ficedula hypoleuca) microsatellite primers at increasing phylogenetic distances (Primmer et al. 1996).

Among the four owl species examined, O. sunia is phylogenetically closest to O. e. botelensis (Severinghaus, unpublished data). These two species may share a high proportion of sequences flanking the microsatellites with $O$. e. botelensis, so that all the $O$. e. botelensis primers were successfully PCRamplified in $O$. sunia. In fact, most of these microsatellite loci turn out to be more polymorphic in $O$. sunia than in $O$. e. botelensis, even though we preferentially screened for microsatellites containing longer repeat motifs during enrichment cloning which should have made them more polymorphic in $O$. e. botelensis Table 3. The difference in polymorphism between these two species could

Table 3. Results of cross-species test of microsatellite primer pairs on four species of owls

\begin{tabular}{|c|c|c|c|c|c|c|c|c|}
\hline \multirow[t]{2}{*}{ Locus } & \multicolumn{2}{|c|}{ Ninox scutulata } & \multicolumn{2}{|c|}{ Otus lettia } & \multicolumn{2}{|c|}{ O. spilocephalus } & \multicolumn{2}{|c|}{ O. sunia } \\
\hline & $N_{A} / N^{\mathrm{a}}$ & $H_{O}{ }^{\mathrm{b}}$ & $N_{A} / N$ & $H_{O}$ & $N_{A} / N$ & $H_{O}$ & $N_{A} / N$ & $H_{O}$ \\
\hline Oe3-7 & $0 / 15$ & - & $5 / 36$ & 0.417 & $8 / 22$ & 0.727 & $10 / 27$ & 0.963 \\
\hline Oe3-21 & $1 / 15$ & - & $1 / 37$ & - & $1 / 23$ & - & $15 / 27$ & 0.556 \\
\hline Oe2-57 & $0 / 15$ & - & $12 / 36$ & 0.833 & $11 / 23$ & 0.957 & $23 / 27$ & 0.815 \\
\hline Oe022 & $1 / 15$ & - & $1 / 37$ & - & $3 / 23$ & 0.739 & $8 / 27$ & 0.259 \\
\hline Oe045 & $0 / 15$ & - & $3 / 37$ & 0.405 & $6 / 23$ & 0.913 & $16 / 25$ & 0.64 \\
\hline Oe050 & $1 / 15$ & - & $1 / 37$ & - & $1 / 23$ & - & $2 / 27$ & 0.037 \\
\hline Oe053 & $1 / 15$ & - & $7 / 37$ & 0.757 & $5 / 23$ & 0.652 & $9 / 27$ & 0.63 \\
\hline Oe054 & $0 / 15$ & - & $6 / 37$ & 0.676 & $5 / 23$ & 0.522 & $34 / 27$ & 0.778 \\
\hline Oe092 & $7 / 14$ & 0.643 & $8 / 36$ & 0.861 & $5 / 23$ & 0.13 & $18 / 27$ & 0.778 \\
\hline Oe128 & $3 / 15$ & 0.267 & $7 / 37$ & 0.568 & $6 / 23$ & 0.696 & $13 / 27$ & 0.778 \\
\hline Oe142 & $0 / 15$ & - & $5 / 37$ & 0.568 & $7 / 23$ & 0.696 & $14 / 27$ & 0.815 \\
\hline Oe171 & $0 / 15$ & - & $0 / 37$ & - & $5 / 22$ & 0.5 & $13 / 27$ & 0.741 \\
\hline Oe029 & $4 / 15$ & 0.4 & $6 / 34$ & 0.382 & $5 / 23$ & 0.565 & $14 / 27$ & 0.815 \\
\hline Oe081 & $1 / 15$ & - & $1 / 37$ & - & $1 / 23$ & - & $9 / 27$ & 0.63 \\
\hline Oe084 & $1 / 15$ & - & $6 / 37$ & 0.595 & $3 / 23$ & 0.087 & $8 / 27$ & 0.704 \\
\hline Oe085 & $5 / 15$ & 0.8 & $8 / 37$ & 0.919 & $10 / 23$ & 0.696 & $15 / 27$ & 0.704 \\
\hline Oe129 & $4 / 15$ & 0.467 & $7 / 37$ & 0.568 & $8 / 23$ & 0.783 & $6 / 27$ & 0.593 \\
\hline Oe149 & $1 / 15$ & - & $1 / 37$ & - & $5 / 23$ & 0.696 & $9 / 27$ & 0.667 \\
\hline Number of polymorphic loci & 5 & & 12 & & 15 & & 18 & \\
\hline Mean number of alleles per locus ${ }^{b}$ & 4.6 & & 6.67 & & 6.13 & & 13.11 & \\
\hline Overall observed heterozygosity ${ }^{c}$ & 0.427 & & 0.630 & & 0.639 & & 0.660 & \\
\hline
\end{tabular}

${ }^{\mathrm{a}}$ Number of alleles/number of individuals successfully genotyped. ${ }^{\mathrm{b}}$ Only polymorphic loci were averaged. ${ }^{\mathrm{c}}$ Only polymorphic loci were calculated. 
result from the fact that $O$. sunia is widely distributed in East Asia with a large and relatively continuous population (our $O$. sunia samples came from locations spanning ca. $24^{\circ}$ in latitude), while O. e. botelensis population is small and isolated on Lanyu. The effect of genetic drift is usually more pronounced in small populations.

Sixty-seven of the world's 212 species of owls belong to the genus Otus, and 41 of them are Old World species (König et al. 1999). Many Otus owls in East Asia are found only on islands and their population genetics have rarely been studied. The general applicability of microsatellites developed from O. e. botelensis to other Otus owls should proof highly useful when studying the genetic diversity, population differentiation, or conservation of Asian Otus owls.

\section{Acknowledgements}

We thank members of the Lanyu scops owl research team for collecting $O$. e. botelensis blood samples, Prof. J.C. Chang, Prof. J. Song and Mr. H.H. Chiu for providing blood samples from other species of owls, Dr. Y.J. Huang and members of Genetic Diversity Laboratory, Department of Life Science, National Taiwan Normal University for help in lab work. This study was funded by a grant from Academia Sinica, Taipei, Taiwan, a National Science Council grant to LLS (NSC 902313-B-001-036), and a grant to SHL from the Council of Agriculture [COA 90AT-1.3.3-FR1(5)].

\section{References}

Beaumont MA, Bruford MW (1999) Microsatellites in conservation genetics. In: Microsatellite: Evolution and
Application. (eds. DB Goldstein, C Schlötterer), pp. 165182. Oxford University Press, New York.

Beheim J, Eldegard K, Bjørnstad G, Isaksson M, Sonerud G, Heie O, Klungland H (2002) DNA polymorphism in boreal owls (Aegolius funereus). J. Raptor Res., 36, 218-219.

Blouin MS (2003) DNA-based methods for pedigree reconstruction and kinship analysis in natural populations Trends Ecol. Evol., 18, 503-511.

DeSalle R, Schierwater B (eds.) (1998) Molecular Approaches to Ecology and Evolution. Birkhäuser Verlag, Basel.

Gemmell NJ, Akiyama S (1996) An efficient method for the extraction of DNA from vertebrate tissues. Trends Genet., 12, 338-339.

Goudet J (2001) FSTAT, a program to estimate and test gene diversities and fixation indices (Version 2.9.3). Available from http://www.unil.ch/izea/softwares/fstat.html.

Hsu Y-C, Severinghaus LL, Lin Y-S, Li S-H (2003) Isolation and characterization of microsatellite DNA markers from the Lanyu scops owl (Otus elegans botelensis). Mol. Ecol. Notes, 3, 595-597.

Isaksson M, Tegelström H (2002) Characterization of polymorphic microsatellite markers in a captive population of the eagle owl (Bubo bubo) used for supportive breeding. Mol. Ecol. Notes, 2, 91-93.

König C, Weick F, Becking J-H (1999) Owls: A Guide to the Owls of the World, Pica Press, East Sussex.

Korfanta NM, Schable NA, Glenn TC (2002) Isolation and characterization of microsatellite DNA primers in burrowing owl (Athene cunicularia). Mol. Ecol. Notes, 2, 584 585.

Marshall TC, Slate J, Kruuk LEB, Pemberton JM (1998) Statistical confidence for likelihood-based paternity inference in natural populations. Mol. Ecol., 7, 639-655.

Pemberton JM, Coltman DW, Coulson TN, Slate J (1999) Using microsatellites to measure the fitness consequences of inbreeding and outbreeding. In: Microsatellite: Evolution and Application. (eds. DB Goldstein, C Schlötterer), pp. 151-164. Oxford University Press, New York.

Primmer CR, Møller AP, Ellegren H (1996) A wide range survey of cross-species microsatellite amplification in birds. Mol. Ecol., 5, 365-378.

Seutin G, White BN, Boag P (1991) Preservation of avian blood and tissue samples for DNA analysis. Can. J. Zool., 69, 82-90.

Severinghaus LL, Rothery P (2001) The survival rate of Lanyu scops owls Otus elegans botelensis. IBIS, 143, 540-546.

Thode AB, Maltbie M, Hansen LA, Green LD, Longmire LJ (2002) Microsatellite markers for the Mexican spotted owl (Strix occidentalis lucida). Mol. Ecol. Notes, 2, 446-447. 